\title{
Canadian Journal of Forest Research
}

\section{Invasive alien species in protected areas: the dynamics of Pinus taeda at Rio Canoas State Park - Brazil}

\begin{tabular}{|r|l|}
\hline Journal: & Canadian Journal of Forest Research \\
\hline Manuscript ID & cjfr-2021-0148.R1 \\
\hline Manuscript Type: & Article \\
\hline Date Submitted by the & 21 -Sep-2021 \\
\hline Complete List of Authors: & $\begin{array}{l}\text { Ricardo, Bruna; Universidade Federal de Santa Catarina } \\
\text { Siminski, Alexandre; Universidade Federal de Santa Catarina, Campus } \\
\text { Curitibanos } \\
\text { Reis, Maurício; Universidade Federal de Santa Catarina, Fitotecnia }\end{array}$ \\
\hline Keyword: & $\begin{array}{l}\text { Restoration Ecology, Forest Conservation, Invasive species, Conservation } \\
\text { Unit, Atlantic Forest }\end{array}$ \\
\hline $\begin{array}{r}\text { Is the invited manuscript for } \\
\text { consideration in a Special } \\
\text { Issue? : }\end{array}$ & Not applicable (regular submission) \\
\hline &
\end{tabular}

\section{SCHOLARONE ${ }^{\text {M }}$ \\ Manuscripts}


Invasive alien species in protected areas: the dynamics of Pinus taeda at Rio Canoas State Park - Brazil

Bruna Hellen Ricardo ${ }^{1}$, Alexandre Siminski² ${ }^{2}$ Maurício Sedrez dos Reis ${ }^{3}$

1 Postgraduate Programme in Agricultural and Natural Ecosystems (PPGEAN), Federal 2 University of Santa Catarina, Ulysses Gaboardi, km3, Curitibanos, SC, 89520-000, 3 Brazil.brunahricardo@gmail.com.

$4 \quad{ }^{2}$ Postgraduate Programme in Agricultural and Natural Ecosystems (PPGEAN), Federal 5 University of Santa Catarina, Ulysses Gaboardi, km3, Curitibanos, SC, 89520-000, $6 \quad$ Brazil. alexandre.siminski@ufsc.br. Fone 5548 37214170, FAX 554837216467

7 (author responsible for correspondence).

8 3Postgraduate Programme in Agricultural and Natural Ecosystems (PPGEAN), Federal

9 University of Santa Catarina, Ulysses Gaboardi, km3, Curitibanos, SC, 89520-000, 10 Brazil.msedrez@gmail.com. 
1

2

3 Biological invasion is a growing problem, and species of the genus Pinus are known to

\section{ABSTRACT}

Keywords: 1. Restoration Ecology 2. Forest Conservation 3. Invasive species. 4. Conservation Unit

\section{Introduction}

Biological invasion is the second driver of biodiversity loss and species extinction across the world (Bellard et al. 2016). The Convention on Biological Diversity (CBD 
1 2002) defined invasive alien species (IAS) as "species whose introduction and/or spread

2 outside their natural past or present distribution threatens biological diversity". IAS can

3 also bring consequences to human well-being and livelihood (Mazza et al. 2014;

4 Shackleton et al., 2018; Kumar and Singh, 2020). As pointed out by Shackleton et al.

5 (2018) in a review of 51 sources, invasive species harm livelihoods and increase

6 vulnerability through encroaching on land and reducing mobility or access. They can also

7 decrease the supply of natural resources used by households and reduce agricultural

8 production oflivestock and/or crops, resulting in losses of income and increased

9 vulnerability.

Several tree species are responsible for biological invasions, including those belonging to the genus Pinus (Dodet and Collet 2012). This genus plays an important economic role locally, nationally, and worldwide (FAO 2016; Cubbage et al. 2020). However, its forestry over time has resulted in biological invasion in the regions adjacent to plantations, likely promoted by a series of ecological traits, such as easy establishment, fast growth, anemophily, anemochory, high propagule pressure and short generation time (Dodet and Collet 2012; Bechara et al. 2013; Sampaio et al. 2013).

In Brazil, some species of Pinus are considered invasive (e.g., P. caribaea, P. elliottii, P. oocarpa, P. glabra, P. patula and P. taeda); therefore, several authors have reported on the process of invasion across the Mata Atlântica (Ziller and Galvão 2002; Falleiros et al. 2011; Zenni and Ziller 2011; Bechara et al. 2013, 2014; Zenni and Simberloff 2013; Bognola et al. 2018)and Cerrado (Conciani et al. 2018; Ramos et al. 2019) biomes. ( Besides the threat to biological diversity on a global scale, the ecological risk of invasive species is even greater in protected areas (Spear et al. 2013). Specifically, invasive species pose a threat to the ecology of these areas by compromising long-term 
conservation and associated ecosystem services.. The management of invasive species is considered a priority in Brazilian Conservation Units (CUs) (MMA 2012). Decreasing the threat of invasive species in protected areas is essential. However, IAS management control is chronically lacking, and this opens the door to the advance of biological invasions (Ziller and Dechoum 2013).

Biological invasion of Pinus spp.,mainly P. elliottii and P. taeda, in a Brazilian Conservation Unit known as Rio Canoas State Park (PAERC)has been reported (FATMA 2007; Ricardo et al. 2018; Lopes et al. 2019). PAERC is situated at the Brazilian Atlantic Forest plateau, also known as the Araucaria Forest (or Mixed Ombrophilous Forest), an ecosystem which hosts a high degree of species richness and endemism, but troubled by extreme degradation (Ribeiro et al. 2009). PAERC is home to important species of flora and fauna of the Atlantic Forest, including endangered tree species such as Araucaria (Araucaria angustifolia), imbuia (Ocotea porosa), cedro (Cedrela fissilis) and the tree fern Xaxim (Dicksonia sellowiana) (FATMA 2007).

Here, we examine the dynamics of biological invasion of Pinus taeda inside PAERC, describing its current status in order to understand the processes of invasion, integrating the temporal scales of past (already installed), present (seed rain) and future (soil seed bank), to suggest actions to control Pinus and support alternative approaches for restoration and management strategies in CUs.

\section{Material and methods}

\section{Study area}

The study was carried out at Rio Canoas State Park (PAERC) located in the municipality of Campos Novos, Santa Catarina State, southern Brazil. The Park was created in 2004 as environmental compensation from Campos Novos Hydroelectric 
1 Power Plant and Dam. PAERC consists of 1,133.25 ha and id surrounded by a boundary

2 zone around the park of 3,105.24 ha (Figure 1) (FATMA 2007).

4 Deciduous Seasonal Forest, both ecosystems of the Brazilian Atlantic biome (FATMA

5 2007). The climate is classified as subtropical, superhumid mild mesothermal - Cfa,

6 according to the Köppen Climate Classification System (Alvares et al. 2013). Average

7 annual temperature is $16.5^{\circ} \mathrm{C}$, annual rainfall is $1,780 \mathrm{~mm}$. The area experiences 6 to 19

8 annual frosts (Nogueira et al. 1987). The soil types found are Latosol and Cambisol, all

9 alic with a humic or prominent surface horizon (Embrapa 2004). The study area is situated

10 on the Geomorphological Unit Rio Iguaçu/Rio Uruguai. It is characterized by an intense

11 dissection of the plateau, along with the main drainage by the Canoas river, and large

12 slopes between valleys (Lopes et al. 2019).

After the creation of PAERC in 2004, evidence of invasion, mainly by P. taeda,

was soon identified, ushering in the first control actions carried out in 2008. However, with the lack of maintenance, came subsequent invasion outbreaks (FATMA 2007). Recent analysis of the landscape surrounding PAERC indicated 523.2 hectares of Pinus spp. forestry at the CU's boundary (Ricardo et al. 2018), as well as more than 5,000 ha within a $10 \mathrm{~km}$ radius of the park (Lopes et al. 2019).

Our study area was located at the northern and southern borders, covering approximately 91.3 ha, termed as the "recovery zone" in the management plan (FATMA 2007), where a Pinus taeda plantation was removed in 2008. We also included plots along the main northeast-southwest internal road., .

\section{Sampling and assessment}


Vegetation in three different successional stages were included in the sampling: 1) Old Growth Vegetation (OGV), i.e., native forest at an advanced stage of regeneration with no record of invasive species; 2) Pinus invasion (EPI), i.e., areas with Pinus taeda invasion after removal (recovery zone); and 3) Initial Vegetation (EIV), i.e., areas in the initial stage of regeneration with no previous record of invasion. However, in the latter case, we assumed a risk of invasion based on such favorable features as open canopy and proximity to Pinus spp. plantations located in the boundary zone.

Based on field assessments, sample units of 200 meter linear transects were established with three $20 \times 20 \mathrm{~m}$ plots $\left(400 \mathrm{~m}^{2}\right)$, maintaining a spacing of $60 \mathrm{~m}$ between plots and distance of $10 \mathrm{~m}$ from edges, totaling 11 transects and 33 plots surveyed (Figure 1). The sampling intensity covered $1.5 \%$ of the recovery zone (Kersten and Galvão 2011). From the total area sampled $\left(13,200 \mathrm{~m}^{2}\right)$, nine plots $\left(3,600 \mathrm{~m}^{2}\right)$ were in OGV, six plots $\left(2,400 \mathrm{~m}^{2}\right)$ in EIV, and 18 plots $\left(7,200 \mathrm{~m}^{2}\right)$ in EPI.

Each plot $(20 \times 20 \mathrm{~m})$ was again divided into four $10 \times 10 \mathrm{~m}$ subplots in which we carried out: I) Total plot $\left(400 \mathrm{~m}^{2}\right)$ - forest inventory considering tree individuals with DBH (Diameter at Breast Height at $1.3 \mathrm{~m}$ ) $\geq 10 \mathrm{~cm}$; II) Subplot 1- inventory of all individuals with $\mathrm{DBH}<10 \mathrm{~cm}$ (regeneration); III) Subplot 2- sample of the soil seed bank at the site; and IV) Subplot 3: collectors installed to evaluate seed rain.

Density (number of individuals per hectare), mean of $\mathrm{DBH}$, basal area (BA) in meters per hectare (m.ha-1 ), and ratio in percentage of the basal area, always considering two categories, i.e., Pinus spp. and other species, were measured.

To assess germination potential of the seed bank, soil samples of $25 \mathrm{~cm} \times 25 \mathrm{~cm}$ x $5 \mathrm{~cm}$ (as per Brown 1992) and litter, were taken in summer (February 2018) and winter (June 2018).. After storage in identified plastic bags, samples were placed in perforated plastic trays, and covered with a first layer of commercial forest substrate measuring 2 
$1 \mathrm{~cm}$ in depth.. A sample from the seed bank was placed above the first layer, and the litter

2 was positioned on the surface. Seed bank samples were maintained in a greenhouse, and

3 irrigated daily for a period of 120 days at an average temperature of $24^{\circ} \mathrm{C}$. Seedling

4 growth was measured monthly and separated into: Pinus and other species.

To evaluate seed rain, permanent $1 \mathrm{~m}^{2}$ seed wood frame collectors covered with

6 screen/shading fabric were placed in each plot at a height of $0.8 \mathrm{~m}$ from the ground. Six

7 seed collections were placed in December 2017 and then February, April, June, August

8 and October of 2018. The material was also separated into Pinus and other species. Seeds

9 showing no damage were visually evaluated and considered in the counting. The density

10 of Pinus seeds, as well as other species, was quantified, along with the seasonal pattern

11 of seed dispersal, and the number of seeds was estimated per hectare.

Confidence intervals were calculated according to the variables analyzed, taking into account the three different environments and using R software (R Core Team 2018).

\section{Results}

Considering stem DBH $\geq 10 \mathrm{~cm}$, Pinus taeda individuals were found in EPI and

EIV, with the highest stem density in EPI where forestry was previously practiced.. Pinus taeda occurred in 50\% of the plots evaluated at EPI and EIV; however, their density was lower than the other species combined (Figure 2). The average of P. taeda DBH ranged from $10,0 \mathrm{~cm}(\mathrm{EPI})$ to $13,6(\mathrm{EIV})$ in the area assessed. Some pinus individuals measured close to $40 \mathrm{~cm}$ of DBH. The dominance of P. taeda in EPI and EIV was approximately $30 \%$ and $50 \%$ of the basal area value, respectively. Concerning regeneration $(\mathrm{DBH}<10$ $\mathrm{cm})$, seedlings of P. taeda were found only in $11 \%$ of plots of EPI, representing around $3 \%$ of stem density and $6,7 \%$ of the basal area . 
Seed rain of Pinus occurred all year long, except in OGV where no pine seeds were found. Seed rain for EPI and EIV showed both temporal and spatial heterogeneity (Figure 3).The annual volume of Pinus taeda seed dispersion found was 125,000 seeds per hectare in EPI and 404,000 seeds/ha/year in EIV. At the peak of seed rain, over 250,000 seeds of pine per hectare (June 2018) were recorded. In EPI, Pinus taeda seeds were recorded throughout the year in all measurements, and the highest value was recorded in April. The average seeds from other species were higher in October. For EIV, the averages of $P$. taeda seeds were more abundant in June and less abundant in February. Special attention is needed in EIV because Pinus seeds represented more than $50 \%$ of total propagule available during the period of this study.

Concerning seed bank evaluation (Table 1), the summer evaluation (February) showed no development of Pinus taeda seedlings during the emergence period (120 days), only seedlings of other species. The winter evaluation (June), however, had some emergence of $P$. taeda in EIP and EVI. This result could be associated with seed rain data, considering that the second evaluation followed the seed rain peak, as shown in Figure 2.

\section{Discussion}

As expected, Pinus taeda was not found in the OGV plots, which are more structured with the highest mean DBH and basal area. In contrast, $P$. taeda individuals were found in EIV where no previous data were recorded, reinforcing the invasive potential of the species and expanding the occurrence in PAERC. These results supported the lower capacity of the genus to colonize structured environments, such as native forest, even young secondary fragments such as those found in EIV.

Density and basal area values found in EPI and EVI were similar to those of other studies that found around $25 \%$ of stems as pine and up to $50 \%$ of basal area (Menon and 
1 Carvalho 2012; Ramos et al. 2019). This high basal area indicates competition for

2 environmental attributes, such as light and habitat, which may compromise maintenance

3 and survival of native species in the medium and long term (Ramos et al. 2019).

'The average of BA $\left(22.19 \mathrm{~m}^{2} / \mathrm{ha}\right)$ and $\mathrm{DBH}(19.4 \mathrm{~cm})$ found in the OGV plots were similar to other old-growth forest sites in the region. According to the official

6 Floristic and Forest Inventory of Santa Catarina, forests have an average BA of 26.76

$7 \mathrm{~m}^{2} /$ ha and average DBH of $20.4 \mathrm{~cm}$ (Vibrans et al. 2013).

The structural parameters of EIV were higher than those reported by Siminski et al. $(2011 ; 2021)$ for young secondary forests in the region. The difference could be explained by the presence of individuals of $P$. taeda with high DBH in the area assessed. Some individuals measured close to $40 \mathrm{~cm}$ of $\mathrm{DBH}$, indicating that the invasive process in EIV is long-standing and that control in these areas was lacking during the first management intervention in 2008.

The production of seeds found at PAERC can be an important factor for invasive success of $P$. taeda. A similar pattern, in which a peak in seed rain occurs around the months of April/May, with year round seed rain has been found in other studies in the Atlantic Forest (Bechara et al. 2013, 2014; Fockink et al. 2020).

The annual volume of Pinus taeda seed dispersion found in this study $(125,000$ seeds/ha/year in EPI and 404,000 seeds/ha/year in EIV) is lower than that obtained by Bechara et al. $(2013 ; 2014)$ with 2 million Pinus elliotti seeds/ha/year, or that of Fockink et al. (2020) with 750.000 Pinus taeda seeds/ha/year. However, studies in the literature have recorded seed rain values in areas adjacent to forestry stands where the density of $P$. taeda is higher than that found in PAERC.

These EPI and EIV areas deserve attention as they are located closer to the park's border, which means that they are more susceptible to invasion from boundary zone 
1 plantations, as consequence of the anemochoric dispersion of seeds. The average

2 dispersion distance of Pinus seeds is between 50 and 300 meters (Nathan et al. 2002;

3 Williams et al. 2006; Tomazello et al. 2017), but it can reach as far away as $5 \mathrm{~km}$,

4 depending on the direction and speed of the wind (thermal uplift), topography, and

5 vegetation successional stage (Zanchetta and Pinheiro 2007).

6 Anemochoric dispersion increases susceptibility to invasion in locations with

7 higher solar incidence or vegetation in early stages of regeneration, even without trees

8 (Higgins and Richardson 1998; Zenni and Simberloff 2013). Sometimes, a single

9 reproductive individual may become the source of invasion; as estimated by Bechara et

10 al. (2014), a single $P$. elliottii tree (30-40 years old) may disperse 2,500 viable seeds ha-

111 per year.

The results also suggest that the Pinus taeda seed bank is ephemeral. This conclusion is based on the failure of seeds dispersed in the previous year to germinate in the summer season. . Seeds of $P$. elliottii were only viable when stored for 90 days in the soil of an area in the restinga, a sandy coastal ecosystem associated with the Atlantic Forest biome, suggesting a transient seed bank species (Bechara et al. 2013). The low seed viability in the soil may seem like an advantage to control Pinus invasion, but continuous seed rain represents a constant threat of reinfestation (Bechara et al. 2014).

Seed bank composition depends on the history of vegetation cover and stock age, comprising a dynamic system whereby the accumulated stock varies according to inputs and outputs (Martínez-Ramos and Soto-Castro, 1993). The density of other species in the seed bank was ten times lower than the results of Martins and Engel (2007) who evaluated soil seed banks in tropical forest fragments with different disturbance histories in Brazil. 
1 account the possibility of recovering soil seed bank processes and dynamics (Martins and $2 \quad$ Engel 2007).

The impact on forest regeneration caused by the pine's biological invasion,

4 particularly at EIP and EIV, calls for its immediate control and eradication, combined with

5 a restoration strategy to recover native biodiversity and a program to manage re-

6 infestation, including the cutting of isolated reproducing trees (Bechara et al. 2013;

7 Ferracin et al. 2013). Regrowth was not observed in stumps cut at $10 \mathrm{~cm}$ above ground

8 (Bognola et al. 2018). Equally important, a prevention system for invasive alien species

9 must be urgently implemented in Brazilian protected areas (Ziller and Dechoum 2013).

therefore, it appears that an integrative restoration approach, i.e., one that includes passive restoration, nucleation and plantation, would be a suitable strategy by which to achieve a naturally growing forest, considering inputs, costs, and divergence from natural processes (Vogel et al, 2015; Bechara et al. 2016; Meli et al. 2017; Trentin et al., 2018). companies and boundary residents to build an alternative for pine forestry activities. the species persists in former forestry sites and initial regeneration environments, leading to the need for the removal of individuals inside PAERC. The seed bank and seed rain analyses suggest that autumn (April, May and June) is the season that deserves more 
1 attention because that is when the largest Pinus seed dispersion occurs. Although the

2 Pinus seed bank was not shown to be persistent, in other words ephemeral, continuous

3

\section{Acknowledgment}

We thank FAPESC for the scholarship (Edital de chamada pública ${ }^{\circ}$ 03/2017), PPGEAN for supporting the research, and the Instituto de Meio Ambiente (IMA Research authorization $\mathrm{N}^{\circ}$ 09/2016) and Grimpeiro - Grupo de Apoio à Gestão das Unidades de Conservação for supporting fieldwork. We also thank Daisy Christiane Zambiazi for Figure 1.

\section{References}

Alvares CA, Stape JL, Sentelhas PC, de Moraes Gonçalves JL, Sparovek G. (2013). Köppen's climate classification map for Brazil. Meteorologische Zeitschrift 22, 711-728. DOI:

Bechara FC, Reis A, Bourscheid K, Vieira NK, Trentin BE. (2013) Reproductive biology and early establishment of Pinus elliottii var. elliottii in Brazilian sandy coastal plain vegetation: implications for biological invasion. Scientia Agricola 70(2), 88-92. DOI:

Bechara FC, Reis A, Trentin BE. (2014) Invasão biológica de Pinus elliottii engelm. Var. elliottii no Parque Estadual do Rio Vermelho, Florianópolis, SC. Floresta 44: 63-72 DOI: http://dx.doi.org/10.5380/rf.v44i1.32013

Bechara FC, Dickens SJ, Farrer EC, Larios L, Spotswood EN, Mariotte P. (2016) Neotropical rainforest restoration: comparing passive, plantation and nucleation approaches. Biodiversity Conservation 25:2021-2034. DOI: https://doi.or/10.1007/s10531-016-1186-7 
1 Bellard C, Cassey P, Blackburn TM. (2016) Alien species as a driver of recent extinctions. 2 Biological Letters 12: 20150623. DOI: http://dx.doi.org/10.1098/rsbl.2015.0623

Bognola IA, Lavoranti OJ, Higa AR, Coutinho RT, Bobko, A, Ribas Junior U. (2018) Dispersão de sementes, regeneração e rebrota de Pinus taeda no Planalto Norte do Estado de Santa Catarina, Brasil. Pesquisa Florestal Brasileira 38, 1-10. DOI: https://doi.org/10.4336/2018.pfb.38e201801651.

Brown D. (1992) Estimating the composition of a forest seed bank: a comparison of the seed extraction and seedling emergence methods. Canadian Journal of Botany 70:10631612. DOI: https://doi.org/10.1139/b92-202.

Convention on Biological Diversity. (2002). COP 6 Decision VI/23, Alien species that threaten ecosystems, habitats or species Retrieved from http://www.cbd.int/decision/cop/?id=7197

Conciani D, Silva Y, Zanchetta D, Ruffino PH. (2018) Temporal analysis of biological invasion by Pinus spp. in humid area of Cerrado domain. Revista Brasileira de Geografia Física 11, 521-531. DOI: https://doi.org/10.26848/rbgf.v11.2.p521-531.

Cubbage F, Kanieski B, Rubilar R, Bussoni A, Olmos VM, Balmelli G, Mac Donagh P, Lord R, Hernández C, Zhang P, Huang J, Korhonen, J, Yao R, Hall P, Del La Torre R, Diaz-Balteiro L, Carrero O, Monges E, Thu HTT, Frey G, Howard M, Chavet M, Mochan, S, Hoeflich VA, Chudy R, Maass D, Chizmar S, Abt R. (2020) Global timber investments, 2005 to 2017, Forest Policy and Economics 112, 102082. DOI: https://doi.org/10.1016/j.forpol.2019.102082

Dodet M, Collet C. (2012) When should exotic forest plantation tree species be considered as an invasive threat and how should we treat them?. Biological Invasions 14, 1765-1778. DOI: https://doi.org/10.1007/s10530-012-0202-4

Embrapa. (2004). Solos do Estado de Santa Catarina. Boletim de pesquisa e desenvolvimento. ISSN 1678-0892.

Falleiros RM, Zenni RD, Ziller S R. (2011) Invasão e manejo de Pinus taeda em campos de altitude do Parque Estadual do Pico Paraná, Paraná, Brasil. Floresta 41, 123-134. DOI: http://dx.doi.org/10.5380/rf.v41i1.21193.

FAO. (2016). Global Forest Resources Assessment 2015. How are the world's forests changing? (2nd Ed.). Rome: Food and Agriculture Organization of the United Nations. Available at http://www.fao.org/3/a-i4793e.pdf.

FATMA, Fundação do Meio Ambiente do Estado de Santa Catarina. (2007) Plano de Manejo Parque Estadual Rio Canoas. Encarte 1, Contextualização da Unidade de Conservação. http://www.fatma.sc.gov.br/conteudo/parqueestadualrio-canoas [Accessed 18.06.2018].

Ferracin TP, Medri PS, Batista ACR, Mota MC, Bianchini E, Torezan JMD. (2013) Passive Restoration of Atlantic Forest Following Harvesting in Southern Brazil. RestorationEcology21, n. 6, p. 770 -776. DOI: https://doi.org/10.1111/rec.12005. 
1 Fockink GD, Pech, TM, Silva M, Siminski A, Niemeyer J C. (2020) Influence of aciculas 2 deposition on natural regeneration in sub-woods of Pinus taeda L. forest stand. Floresta 3 50(1): 1071-1080. DOI: https://doi.org/10.5380/rf.v50i1.611361071

4 Higgins SI, Richardson DM. (1998) Pine invasions in the southern hemisphere: modelling 5 interactions between organism, environment and disturbance. Plant Ecology v. 135, p. 6 79-93, 1998. DOI: https://doi.org/10.1023/A:1009760512895

7 IMA, Instituto do Meio Ambiente de Santa Catarina. Biodiversidade: Unidades de 8 Conservação. http://ima.sc.gov.br/index.php/ecosistemas/unidades-de-conservacao $9 \quad$ [Accessed 01.03.2018].

Kersten RA, Galvão R. (2011) Suficiência amostral em inventário florísticos e fitossociológicos. Fitossociologia no Brasil: métodos e estudos de casos. Volume 1. Viçosa, Editora UFV.

Kumar RP, Singh JS. (2020) Invasive alien plant species: Their impact on environment, ecosystem services and human health. Ecological Indicators 111:106020. DOI: .

Lopes MS, Veettil BK, Saldanha DL. (2019) Assessment of Small-Scale Ecosystem Conservation in the Brazilian Atlantic Forest: A Study from Rio Canoas State Park, Southern Brazil. Sustainability 11. 2948. DOI: https://doi.org/10.3390/su11102948.

Martínez-Ramos M, Soto-Castro A. (1993) Seed rain and advanced regeneration in a tropical rain forest. Vegetation 107/108: 299-318.

Martins AM, Engel VL. (2007) Soil seed banks in tropical forest fragments with different disturbance histories in southeastern Brazil. Ecological Engineering 31:165-174. DOI: https://doi.org/10.1016/j.ecoleng.2007.05.008.

Mazza G, Tricarico E, Genovesi P, Gherardi F. (2014) Biological invaders are threats to human health: an overview, Ethology Ecology \& Evolution 26:2-3: 112-129. DOI: https://doi.org/10.1080/03949370.2013.863225.

Meli P, Holl KD, Rey Benayas JM, Jones HP, Jones PC, Montoya D. (2017) A global review of past land use, climate, and active vs. passive restoration effects on forest recovery. PLoS ONE 12(2): e0171368. DOI:

Menon T, Carvalho F. (2012) Estrutura populacional de Pinus elliottii em áreas de regeneração florestal em Juiz de Fora, MG. Pesquisa Florestal Brasileira 32(72), 367. DOI:https://doi.org/10.4336/2012.pfb.32.72.367

MMA (2012). The National System of Protected Areas. www.mma.gov.br/estruturas/sbf2008_dap/_publicacao/149_publicacao0507201105295 1.pdf

Nathan R, Katul GG, Horn HS, Thomas SM, Oren R, Avissar R Stephen W. Pacala, Simon A. Levin. (2002). Mechanisms of long-distance dispersal of seeds by wind. Nature 418(6896): 409-413.DOI: http://dx.doi.org/10.1038/nature00844 
Nogueira, A. C.; Kuniyoshi, Y. S.; Soares, R. V. (1987) Zonas de vida para o estado de Santa Catarina segundo a classificação das formações vegetais de Holdridge. Revista Floresta 17, n. 1-2, p. 103-112. DOI: http://dx.doi.org/10.5380/rf.v17i12.6372.

R Core Team. (2018) R: A language and environment for statistical computing. R Foundation for Statistical Computing, Vienna, Austria. https://www.R-project.org/ [accessed 30.05.2018].

Ramos M, Magro T, Couto H, and Castro T. (2019) Dispersão e impacto de Pinus elliottii Engelm. var. elliottii em área ripária na Floresta Nacional de Capão Bonito - SP. Ciência Florestal 29(1), 75-85. DOI:http://dx.doi.org/10.5902/1980509825789

Ribeiro MC, MetzgerJP, MartensenAC, Ponzoni FJ, Hirota MM. (2002) The Brazilian Atlantic Forest: How much is left, and how is the remaining forest distributed? Implications for conservation. Biological Conservation 142(6): 1141-1153. DOI: .

Ricardo BH, Siminski A, Reis MS. (2018) Inventário florestal como ferramenta para o diagnóstico da invasão biológica de Pinus sp. no Parque Estadual Rio Canoas - SC. In: Anais da II Semana de Aperfeiçoamento em Engenharia Florestal da UFPR : $<$ https//www.even3.com.br/anais/iiseaflor/98010-INVENTARIO-FLORESTALCOMO-FERRAMENTA-PARA-O-DIAGNOSTICO-DA-INVASAO-BIOLOGICADE-PINUS-SP-NO-PARQUE-ESTADUAL-RIO-C $>$. [Accessed : 12.12.18].

Sampaio AB, Schimidt IB. (2013) Espécies Exóticas Invasoras em Unidades de Conservação Federais do Brasil. Biodiversidade Brasileira 3(2): 32-49.

Shackleton R, Shackleton C, Kull C. (2018) The role of invasive alien species in shaping local livelihoods and human well-being: A review. Journal of Environmental $\begin{array}{lll}\text { Management } 229 . & 10.1016 / \text { j.jenvman.2018.05.007. DOI: }\end{array}$ 10.1016/j.jenvman.2018.05.007

Siminski A, Fantini AC, Guries RP, Ruschel AR, Reis MS. (2011) Secondary Forest Succession in the Mata Atlantica, Brazil: Floristic and Phytosociological Trends. ISRN ECOLOGY 1-19. DOI: https://doi.org/10.5402/2011/759893

Siminski A, Zambiazi DC, Santos KL dos, Fantini AC. (2021). Dynamics of Natural Regeneration: Implications for Landscape Restoration in the Atlantic Forest, Brazil. Frontiersin Forests and Global Changes 4, 576908. DOI: https://doi.org/10.3389/ffgc.2021.576908

Spear D, Foxcroft LC, Bezuidenhout H and McGeoch MA. (2013) Human population density explains alien species richness in protected areas. Biological Conservation 159, 137-147. DOI: https://doi.org/10.1016/j.biocon.2012.11.른

Tomazello-Filho M, Latorraca JVF, Fischer FM et al. (2017) Avaliação da dispersão de sementes de Pinus taeda L. pela análise dos anéis de crescimento de árvores de regeneração Natural. Floresta e Ambiente 24. DOI:https://doi.org/10.1590/2179$\underline{8087.040913}$ 
1 Trentin BE, Estevan DA, Rossetto EFS, Gorenstein MR, Brizola GP, Bechara FC. (2018).

2 Restauração florestal na mata atlântica: passiva, nucleação e plantio de alta diversidade.

3 Ciência Florestal 28, 160-174. DOI:

4 Vibrans AC, Sevegnani L, Gasper AL, Lingner DV. (2013) Inventário Florístico Florestal 5 de Santa Catarina - Volume III, Floresta Ombrófila Mista. Edifurb, 440 p.

6 Vogel HF, Campos JB, Bechara, CF. (2015) Early bird assemblages under different 7 subtropical forest restoration strategies in Brazil: passive, nucleation and high diversity 8 plantation. Tropical Conservation Science 8 (4): 912-939. DOI: 9 https://doi.org/10.1177/194008291500800404

10 Williams CG, Ladeau SL, Oren R, Katul GG. (2006) Modeling seed dispersal distances: 11 Implications for transgenic Pinus taeda. Ecological applications 16(1), p117-124.

Zanchetta D, Pinheiro LS. (2007) Análise biofísica dos processos envolvidos na invasão biológica de sementes de Pinus elliottii na Estação Ecológica de Itirapina - SP e alternativas de manejo. Climatologia e Estudos da Paisagem 2(1): 72-90.

Zenni RD, Simberloff D. (2013) Number of source populations as a potential driver of pine invasions in Brazil. Biological Invasions 15:1623-1639. DOI: https://doi.org/10.1007/s10530-012-0397-4Zenni, RD, Ziller, SR. (2011) An overview of invasive plants in Brazil. Brazilian Journal of Botany 34(3), 431-446. DOI: https://dx.doi.org/10.1590/S0100-84042011000300016

Ziller SR, Dechoum MS. (2013) Plantas e vertebrados exóticos invasores em Unidades de Conservação. Biodiversidade Brasileira 3, 2, 04-31. contaminação biológica de Pinus elliotti Engelm. e P. taeda. L. Floresta 32, 1, 41-47. 
1 Table 1. Estimated number of seedlings emerged per hectare (with the relevant 95\% 2 confidence intervals) of Pinus taeda and other species in different successional stage of $3 \quad$ PAERC based on samplings carried out in summer (February) and winter (June).

4

\begin{tabular}{|c|c|c|c|c|c|c|}
\hline \multirow[b]{2}{*}{$\begin{array}{c}\text { Greenhouse } \\
\text { period } \\
\text { (days) }\end{array}$} & \multicolumn{2}{|c|}{ Old Growth Vegetation } & \multicolumn{2}{|c|}{ Pinus invasion } & \multicolumn{2}{|c|}{ Initial Vegetation } \\
\hline & $\begin{array}{c}\text { Pinus } \\
\text { seedlings } \\
\left(\mathrm{x} 10^{6}\right) \\
\end{array}$ & $\begin{array}{c}\text { Other } \\
\text { seedlings } \\
(\mathrm{x} \mathrm{106}) \\
\end{array}$ & $\begin{array}{c}\text { Pinus } \\
\text { seedlings } \\
\left(\mathrm{x} 10^{6}\right) \\
\end{array}$ & $\begin{array}{c}\text { Other } \\
\text { seedlings } \\
\left(\mathrm{x} 10^{6}\right) \\
\end{array}$ & $\begin{array}{c}\text { Pinus } \\
\text { seedlings } \\
\left(\mathrm{x} 10^{6}\right) \\
\end{array}$ & $\begin{array}{c}\text { Other } \\
\text { seedlings } \\
\left(\mathrm{x} \mathrm{10^{6 } )}\right. \\
\end{array}$ \\
\hline \multicolumn{7}{|c|}{ Summer sampling (February 2018) } \\
\hline 30 days & 0 & $\begin{array}{c}4.78 \\
2.91-6.64\end{array}$ & 0 & $\begin{array}{c}8.18 \\
5.62-10.74\end{array}$ & 0 & $\begin{array}{c}8.96 \\
3.92-13.99\end{array}$ \\
\hline 60 days & 0 & $\begin{array}{c}2.41 \\
0.67-4.16\end{array}$ & 0 & $\begin{array}{c}6.15 \\
4.6-7.69\end{array}$ & 0 & $\begin{array}{c}8.58 \\
4.91-12.26\end{array}$ \\
\hline 90 days & 0 & $\begin{array}{c}4.0 \\
1.78-6.39\end{array}$ & 0 & $\begin{array}{c}4.18 \\
2.42-5.94\end{array}$ & 0 & $\begin{array}{c}5.49 \\
2.34-8.64\end{array}$ \\
\hline 120 days & 0 & $\begin{array}{c}4.81 \\
3.27-6.36 \\
\end{array}$ & 0 & $\begin{array}{c}5.79 \\
4.32-7.26 \\
\end{array}$ & 0 & $\begin{array}{c}7.28 \\
4.63-9.92 \\
\end{array}$ \\
\hline \multicolumn{7}{|c|}{ Winter sampling (June 2018) } \\
\hline 30 days & 0 & $\begin{array}{c}6.59 \\
3.64-9.54\end{array}$ & $\begin{array}{c}0.01 \\
-0.006-0.04\end{array}$ & $\begin{array}{c}9.40 \\
6.79-12.01\end{array}$ & 0 & $\begin{array}{c}19.28 \\
6.43-32.12\end{array}$ \\
\hline 60 days & 0 & $\begin{array}{c}2.11 \\
1.38-2.84\end{array}$ & $\begin{array}{c}0.008 \\
-0.008-0.02\end{array}$ & $\begin{array}{c}6.16 \\
3.93-8.39\end{array}$ & $\begin{array}{c}0.02 \\
-0.02-0.07\end{array}$ & $\begin{array}{c}12.0 \\
-0.03-24.03\end{array}$ \\
\hline 90 days & 0 & $\begin{array}{c}8.35 \\
2.31-1.44\end{array}$ & 0 & $\begin{array}{c}5.64 \\
2.76-8.52\end{array}$ & 0 & $\begin{array}{c}5.92 \\
0.62-11.21\end{array}$ \\
\hline 120 days & 0 & $\begin{array}{c}1.49 \\
0.88-2.1 \\
\end{array}$ & 0 & $\begin{array}{c}3.85 \\
2.90-4.81 \\
\end{array}$ & 0 & $\begin{array}{c}3.78 \\
0.83-6.73 \\
\end{array}$ \\
\hline
\end{tabular}

5 
1 Figure 1. Location of Rio Canoas Park and its boundary zone (IMA 2020). Source: 2 http://mapas.sosma.org.br/ (SOS Mata Atlântica 2020); IBGE (2016); Application Area 3 Map of Law n ${ }^{\circ} 11.428 / 2006$ (BRASIL 2006); drawn by Daisy Christiane Zambiazi 4 (2021). Where: 1) Initial Vegetation (EIV); 2) Old Growth Vegetation (OGV); and Pinus 5 invasion (EPI).

6

Figure 2. Structural parameters of 33 plots surveyed at Rio Canoas State Park (PAERC), taking into account individuals with DBH greater than $10 \mathrm{~cm}(\mathrm{DBH} \geq 10 \mathrm{~cm})$ and regeneration (DBH $<10 \mathrm{~cm}$ ). Where: 1) Initial Vegetation (EIV); 2) Old Growth Vegetation (OGV); and Pinus invasion (EPI). The $\mathrm{X}$ inside the boxplots are the average.

Figure 3. Estimated number of seeds of Pinus taeda. and other species (total) collected in the seed rain at PAERC along one year. The data represent the estimated value of seeds per hectare in each of the successional stage evaluated. Where: 1) Initial Vegetation (EIV); 2) Old Growth Vegetation (OGV); and Pinus invasion (EPI). The X inside the boxplots are the average. 


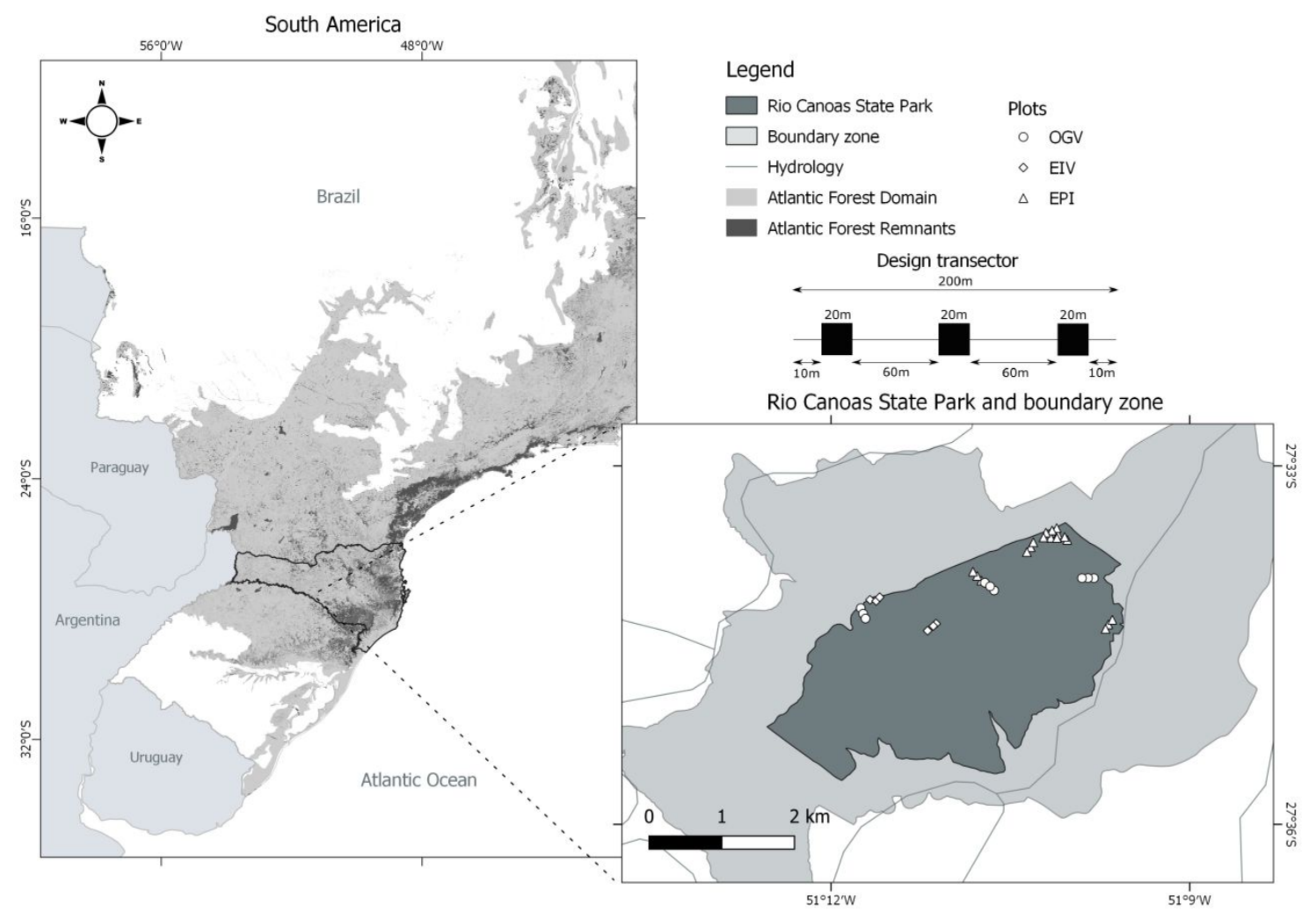

3

4

5

6 


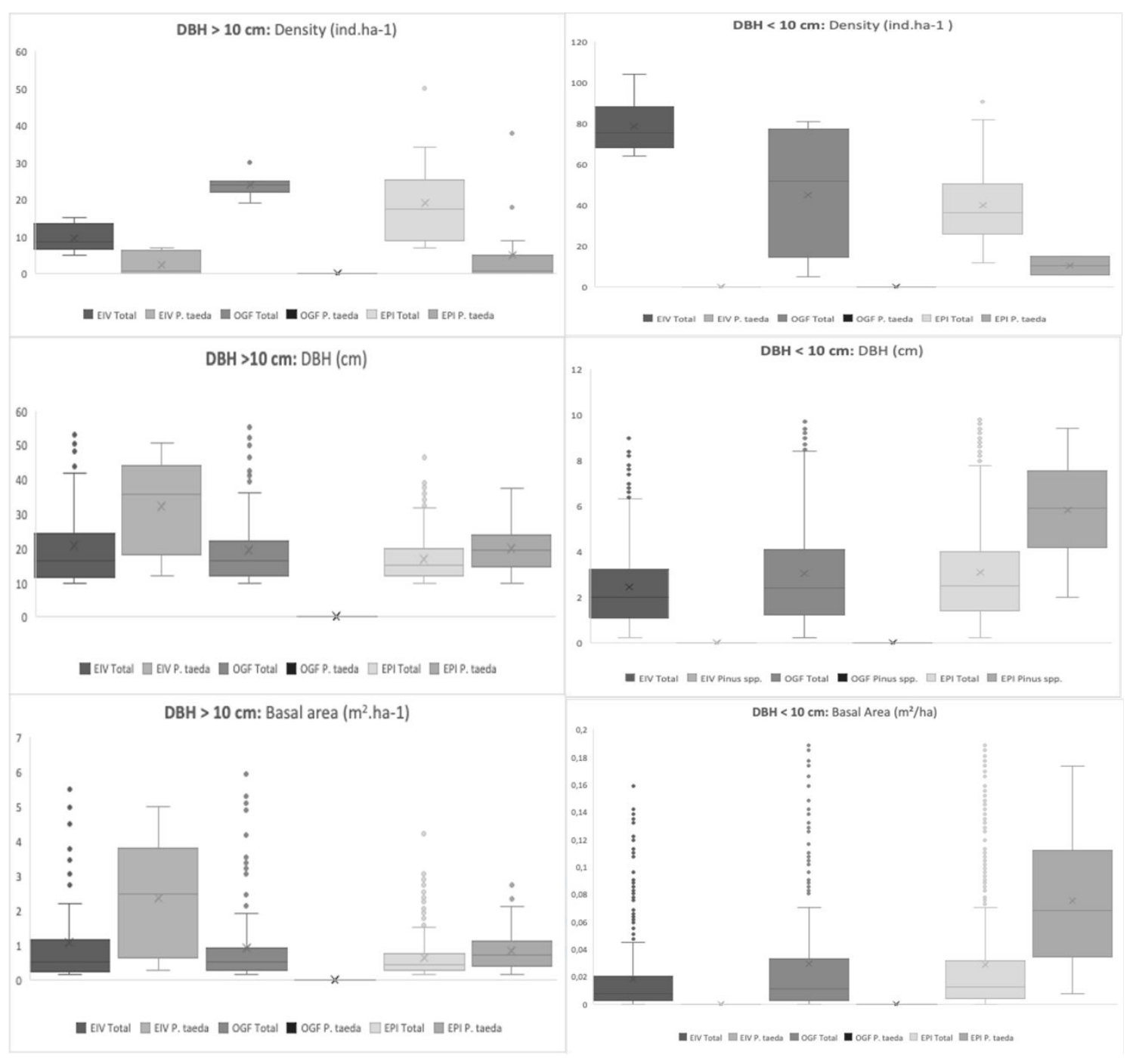

1 3 4 5 6 7 

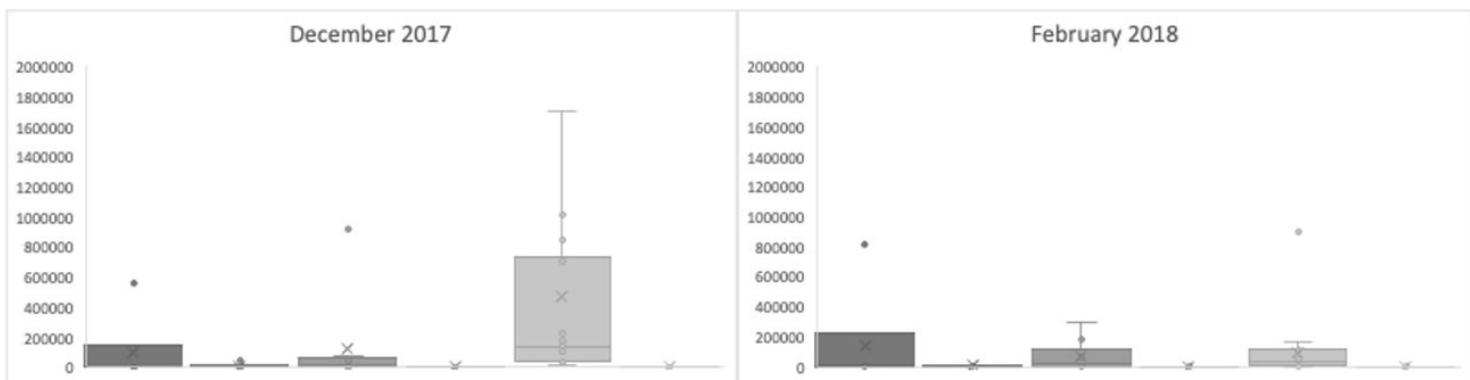

\eIv Total $\square$ EIVP. taeda $\square$ OGV Total $\square$ OGV P. taeda $\square$ EPI Total $\square$ EPIP. taeda

घEVITotal $\square$ EVIP. total $\square$ OGV Total $\square$ OGV P. taeda $\square$ EPI Total $\square$ EPIP. Taeda

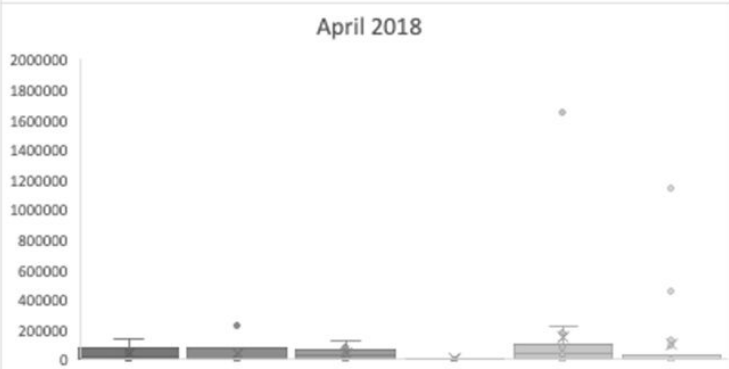

घEV Total $\square$ EVIP. taeda $\square$ OGV Total $\square$ OGV P. taeda $\square$ EPI Total $\square$ EPI P. taeda

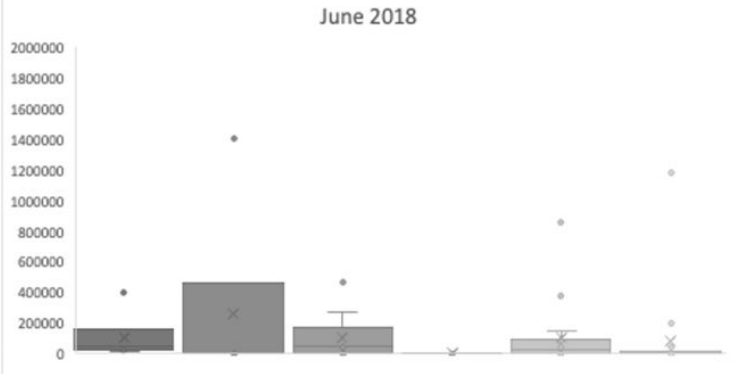

घEV Total $\square$ EIV P. taeda $\square$ oGV Total $\square$ oGVP. taeda $\square$ EPT Total $\square$ EPP P. taeda

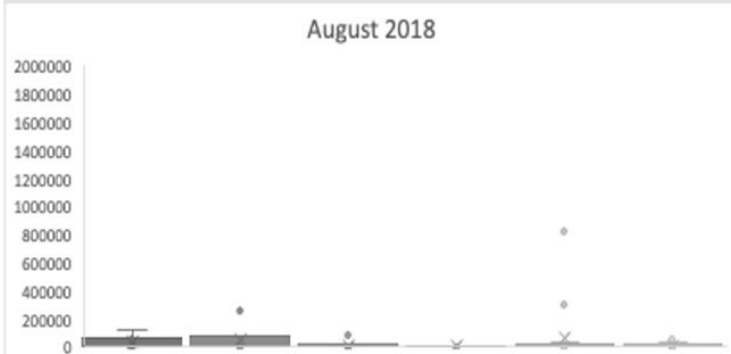

1

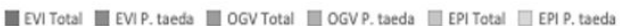

October 2018

2000000

1800000

1600000

1400000

1200000

1000000

800000

600000
400000

200000

00000

घEN Total $\square$ EV P. taeda $\square$ OGV Total $\square$ OGVP. taeda $\square$ EPI Total $\square$ EPIP. taeda 